Riwayat draf artikel: Diserahkan 20-04-2021 Diterima 25-04-2021

\section{Kebijakan Otonomi Perguruan Tinggi sebagai Dampak Reformasi Keuangan dalam Bidang Pendidikan di Indonesia}

Adam $^{1}$, Muryanto Lanontji ${ }^{*}$

Program Studi Pendidikan Guru Pendidikan Anak Usia Dini, Universitas Muhammadiyah Kendari

Progam Studi Ilmu Hukum, Universitas Muhammadiyah

Kendari

Email: Adamin.kotakendari2015@gmail.comㄹ, Muryanto@umkendari.ac.id ${ }^{2}$

\begin{abstract}
ABSTRAK: Tujuan penelitian untuk mendiskripsikan kebijakan otonomi perguruan tinggi sebagai dampak reformasi keuangan dalam bidang pendidikan. Kebijakan otonomi sudah dianggap final, tetapi masih menjadi perdebatan sebab kebijakan otonomi belum diketahui arahnya akan kemana. Banyak kalangan menilai bahwa kebijakan otonomi sebagai bentuk reformasi keuangan dalam penyelenggaraan pendidikan agar perguruan tinggi lebih mandiri dalam urusan keuangan. Perguruan tinggi diberikan tanggung jawab untuk meningkatkan penerimaan negara bukan pajak melalui instrumen pendidikan. Kebijakan otonomi untuk menciptakan transparansi maupun akuntabilitas justru menimbulkan dampak dalam tataran pengelolaannya. Dampaknya perguruan tinggi berusaha secara mandiri untuk menambah income guna membiayai biaya operasional yang tidak memadai. Penelitian menyimpulkan: 1) kebijakan otonomi perguruan tinggi diarahkan untuk berkompetisi dalam berbagai bidang, agar dapat bersaing untuk menjadi universitas bergengsi dan berkelas. 2) perguruan tinggi menginginkan diberikan kebebasan secara desentralistik agar dikelola secara mandiri tanpa intervensi pihak lain. 3) perguruan tinggi dituntut mencari pendanaan untuk meningkatkan penerimaan negara bukan pajak untuk membiayai biaya operasional yang tidak dialokasikan pemerintah. 4) dampak kebijakan otonomi menciptakan praktek komersialisasi, menyebabkan biaya pendidikan yang tidak terjangkau.
\end{abstract}

Kata Kunci: Kebijakan, Otonomi Perguruan Tinggi, Reformasi Keuangan.

\begin{abstract}
The research objective is to describe the autonomy policy of higher education as the impact of financial reforms in education. The autonomy policy is considered final, but it is still a debate because the autonomy policy is not yet known where it will go. Many people think that the autonomy policy is a form of financial reform in the provision of education so that universities are more independent in financial matters. Higher education institutions are given the responsibility to increase non-tax state revenue through educational instruments. The autonomy policy to create transparency and accountability actually has an impact at the level of management. AS a result, universities are trying independently to increase income to finance inadequate operational costs. The research concludes: 1) the autonomy policy of higher education is directed to compete in various fields, in order to be able to compete to become a prestigious and classy university.2) Higher education institutions want to be given decentralized freedom to be managed independently without intervention from other parties. 3) Universities are required to seek funding to increase non-tax state revenue to finance operational costs that are not allocated by the government. 4) The impact of the autonomy policy creates commercialization practices, causing unaffordable education costs.
\end{abstract}

Keywords: Financial Reform, Policy, University Autonomy. 


\section{PENDAHULUAN}

Dalam bidang pendidikan, kebijakan diberlakukan untuk membangun dunia pendidikan agar menghasilkan pengelolaan pendidikan yang berkualitas dan prospektif (Arifin, Juharyanto, Mustiningsih, \& Taufiq, 2018; Juharyanto, Sultoni, Arifin, \& Nurabadi, 2019). Kasus di Indonesia, pendidikannya masih stagnan karena proses penyelenggaraannya dianggap tidak mampu menghasilkan output yang baik dan berkualitas. Secara faktual untuk mendapatkan pendidikan berkualitas, salah satu penentunya adalah kebijakan yang benar dalam bidang pendidikan (H. Hadi, 2016; H. J. Levin, 1987).

Pada tahun 1998 ketika negara Indonesia dilanda krisis moneter yang melemahkan sistem ekonominya, keuangan negara anjlok dan defisit yang mengakibatkan negara kesulitan dalam memenuhi anggaran belanja negara. Kondisi krisis keuangan sangat berpengaruh pada bidang lain termasuk dalam bidang pendidikan. Kesulitan anggaran tersebut turut mempengaruhi penyelenggaraan pendidikan di Indonesia. Untuk mengatasi krisis keuangan, pemerintah mengambil kebijakan reformasi pendidikan dengan menerapkan kebijakan otonomi untuk meningkatkan mekanisme pengelolaan perguruan tinggi agar lebih mandiri dan efisien, sehingga otonomi dapat dipandang sebagai suatu kemandirian (Ghosh, 2018; Karweti, 2010; Sandhu, 2015).

Di Indonesia penerapan kebijakan otonomi perguruan tinggi, diawal kemunculannya banyak mendapat sorotan dan kritikan, sehingga menciptakan polemik berkepanjangan. Kebijakan otonomi diharapkan menciptakan pengelolaan pendidikan secara konprehensif serta ideal tetapi implementasinya mengalami kegagalan (Education, 2011; Lorig \& Holman, 2003; Management \& Education, 2007).

Dalam pandangan politik kebijakan otonomi merupakan jebakan politik untuk meminimalkan peran negara dalam mengatur lembaga perguruan tinggi. Perguruan tinggi diberikan kebebasan dalam mengatur dan mengelola lembaganya tanpa intervensi maupun campur tangan dari pihak manapun, sehingga mengakibatkan pergeseran dan perubahan dinamika termasuk juga perubahan pembiayaan pendidikan. Masyarakat menilai bahwa pendidikan semula dipandang sebagai pendidikan dengan biaya murah tetapi menjadi mahal, sehingga masyarakat tidak bisa mengenyam pendidikan (Education, 2011; Ghosh, 2018; Zainuddin, 2008). Jika perguruan tinggi diberikan otonomi untuk mengatur dan mengelola sendiri lembaganya, tidak menutup kemungkinan lembaga tersebut menjadi lembaga independent yang mengatur sendiri lembaganya serta membuat aturan sendiri yang harus diikuti seluruh civitas perguruan tinggi. Jika kondisi seperti ini terjadi, bisa saja perguruan tinggi menjadi sebuah entitas yang bertanggung jawab sendiri sehingga dapat menciptakan kebebasan atau kekebalan kampus (Icksan, 1985; Sandhu, 2015).

Ketika perguruan tinggi memiliki otonomi dalam menentukan sendiri biaya penyelenggaraan pendidikan, dikhawatirkan perguruan tinggi mematok biaya yang tinggi untuk meningkatkan dan mempertahankan mutu. Dampaknya adalah akses masyarakat yang kurang mampu untuk menikmati pendidikan berkualitas tidak akan terjangkau, sehingga masyarakat akan semakin terkotak- 
kotak berdasarkan status sosial, antara kaya dan miskin. Harapan masyarakat bahwa pendidikan merupakan tanggung jawab pemerintah, sehingga dengan keterbatasan dana tidak menjadi alasan pemerintah untuk tidak mencerdaskan kehidupan bangsa. (Hasbullah, 2016; Rizvi \& Lingard, 2010).

Di beberapa negara terutama Jerman, Prancis, Belanda, dan beberapa negara berkembang lainnya, banyak perguruan tinggi bermutu namun biaya pendidikannya lebih rendah. Di asia tenggara misalnya negara Vietnam, Tiongkok dan negara lainnya justru menggratiskan biaya dan sarana pendidikannya (Nurdin, 2009; Swasono, 2015). Jika dicermati, biaya pendidikan di sejumlah perguruan tinggi negeri besar di Indonesia lebih mahal jika dibandingkan dengan biaya pendidikan di perguruan tinggi swasta yang berkualitas. Harapan masyarakat bahwa perguruan tinggi negeri yang memiliki sarana dan prasarana yang lengkap, gedung yang memadai, laboratorium dan lain sebagainya, seharusnya biaya pendidikannya semakin murah tetapi kenyataannya justru semakin mahal (Fiere \& Illich, 2003; Masditou, 2017; Solihin, 2015).

Walaupun pemerintah menanggung biaya pendidikan dengan proporsi $20 \%$ dari anggaran pendapatan belanja negara dan anggaran pendapatan belanja daerah, tetapi anggaran pendidikan nasional yang dialokasikan ternyata tidak signifikan dengan tujuan pendidikan nasional bahkan banyak di korupsi dan tidak merata (Gusnardi, 2014; Hakim, 2012; Simangunsong, 2018), serta mengalami kebocoran mencapai 30\% (Zainuddin, 2008).

Dewasa ini tantangan pendidikan terbesar yang dihadapi terutama perguruan tinggi adalah isu globalisasi. Isu stategis yang dihadapi perguruan tinggi di indonesia diantaranya adalah daya saing bangsa meliputi integrasi nasional, globalisasi, penelitian dan pendidikan, diferesiasi misi, dan akses terhadap pengetahuan dan otonomi yang berkaitan dengan perubahan peran Pemerintah/Ditjendikti dan tanggung jawab sosial perguruan tinggi(Pratomo, 2002; Sonhadji, 2014), sehingga perguruan tinggi perlu menyikapi berbagai tantangan global secara lebih serius. Sebab pada kenyataannya globalisasi tidak hanya berdampak pada bidang ekonomi tetapi juga berdampak pada dunia pendidikan termasuk pendidikan tinggi.

Kecenderungan globalisasi dipandang bagian dari ekspansi paham neoliberalisme dalam bidang pendidikan dengan dimasukkannya pendidikan dalam General Agreement on Trade in service (GATS) sebagai bidang yang diliberalisasi. Dalam artian bahwa jasa pendidikan termasuk pendidikan tinggi dianggap entitas komersial yang daya saingnya harus dikelola secara maksimal dan professional berdasarkan dorongan pasar. Dengan demikian dorongan liberalisasi pendidikan khususnya pendidikan tinggi merupakan fakta yang sulit untuk dihindari (Darmaningtyas, 2014; Putra, 2012; Suharsaputra, 2015) dan pendidikan tinggi dijadikan komoditas perdagangan jasa pendidikan dan diprediksi pada tahun 2025 Jumlah mahasiswa akan mengalami kenaikan sekitar 25 juta lebih di setiap institusi pendidikan tinggi diseluruh dunia (Van Der Wende, 2003). Jumlah ini merupakan komoditi yang sangat menjanjikan, sebab jasa pendidikan tinggi merupakan jasa pendidikan yang mendapatkan porsi yang paling besar untuk diliberalisasi secara internasional. Sebab pendidikan tinggi 
mencakup semua jenis dan level pendidikan yang ditempuh setelah pendidikan wajib, pendidikan kejuruan, dan jasa pendidikan lainnya (Altbach \& Knight, 2007; Hill, 2003; Van Der Wende, 2003).

Untuk mewujudkan program tersebut cara yang dilakukan adalah menekan negara-negara berkembang dengan menggunakan instrumen utang dan melakukan restrukturisasi dan deregulasi terhadap kebijakan pendidikan. Salah satu contoh adalah pada tahun 1997 ketika terjadi krisis moneter sampai dengan tahun 1999, Bank Dunia dan IMF (International Monetary Fund) memberikan bantuan utang dengan syarat SAP (Structure Adjustment Programe) yang tertuang dalam perjanjian Letter of Intent antara indonesia dan IMF yang mengatur tentang penghematan belanja negara dengan di keluarkannya Peraturan Pemerintah Nomor 60 Tahun 1999 dan Peraturan Pemerintah Nomor 61 Tahun 1999 tentang status Pendidikan Tinggi Negeri berubah status dari lembaga yang berada di bawah Depdiknas menjadi lembaga otonom yang dapat dibantu pihak swasta (Fajar, 2015; S. Hadi, 2004).

Akibat penerapan kebijakan otonomi, perguruan tinggi kehilangan idealismenya, sehingga keberadaan perguruan tinggi menjadi lembaga cepat saji atau mcdonaldisasi (Nugroho, 2002). Komersialisasi pendidikan menjadikan lembaga pendidikan mencari keuntungan dari mengajar, riset, dan aktivitas kampus lainnya (Bok, 2003; Tilaar, 2012). Praktik kapitalisasi, privatisasi maupun komersialisasi muncul disektor pendidikan, terutama pendidikan tinggi, karena sektor pendidikan tinggi merupakan komoditas perdagangan yang menjanjikan keuntungan sangat besar dan dikuasai negara maju pendukung liberalisasi pasar yaitu Amerika Serikat, Inggris dan Australia (Raychaudhuri \& De, 2007; Susanti, 2012).

Otonomi telah merubah arah serta tujuan perguruan tinggi sebagai poros pengembangan pendidikan dan penelitian, serta merubah mindsetnya menjadi sebuah lembaga korporasi yang berorientasi profit. Meskipun pada tataran implementasinya selalu diimbangi dengan berbagai program beasiswa, tetapi pada kenyataan bahwa perguruan tinggi negeri telah secara sadar diarahkan untuk merubah lembaganya menjadi lembaga pendidikan elite dan dikelola berdasarkan prinsip-prinsip ekonomi/bisnis murni dengan tujuan profit oriented (Fiere \& Illich, 2003; Tilaar, 2012).

Otonomi pendidikan membebankan persoalan pendanaan kepada mahasiswa, walaupun pada prakteknya dibumbui dengan prinsip transparansi, akuntabilitas, nirlaba, efektivitas dan efisiensi, tetapi kenyataannya kebijakan otonomi berdampak bagi masyarakat dan masyarakat terbius dengan kebijakan otonomi. Otonomi ibarat obat bius yang berhasil membius kesadaran kritis masyarakat. Dalam sebuah terminologi, otonomi itu mirip candu, sudah tahu tidak enak tetapi dihisap terus (Darmaningtyas, 2015).

Secara ideologis, paradigma akademik yang terbangun selama ini menunjukan bahwa bangsa Indonesia telah sempurna menjadi proyek neoliberalisme yang merupakan konsekuensi logis mengintegrasikan diri ke dalam masyarakat internasional kapitalisme liberal. Dimana bangsa Indonesia mendapat bantuan dari negara-negara kapitalis liberal untuk pembangunan di 
bidang ilmu pengetahuan dan teknologi melalui IMF dan Bank Dunia (Dwiningrum, 2013; Soeharto, 2010; Solihin, 2015; Triharso, 2015). Dengan catatan negara harus mengurangi serta menghilangkan subsidi dalam sektor pendidikan yang ditanggung pemerintah (Sangaji, 2013; Wilson, 2017). Dengan demikian reformasi keuangan dalam bidang pendidikan bertujuan untuk menciptakan kemandirian bagi perguruan tinggi justru menciptakan polemik. Disatu sisi kebijakan otonomi dinilai merupakan sebuah solusi tetapi disisi lain justru menciptakan persoalan lain. Persoalan pendidikan merupakan persoalan yang paling penting sehingga kita perlu belajar dari negara-negara lain yang sudah berkembang dari segi pendidikannya. Negara indonesia harus berani secara politik menempatkan pembangunan pendidikan dan sumber daya manusianya pada prioritas utama, dan tidak ragu menempatkan anggaran pendidikan dengan sangat besar (Hasbullah, 2016; PH, 2014).

\section{METODE PENELITIAN}

Penelitian ini menggunakan rancangan penelitian studi multikasus. Tujuan penelitian adalah menjelaskan kebijakan otonomi perguruan tinggi sebagai dampak reformasi keuangan dalam bidang pendidikan. Teknik pengumpulan data dilakukan dengan cara wawancara langsung dengan direktur, wakil rektor, wakil direktur, mahasiswa, orang tua mahasiswa, penelaahan dokumen-dokumen dan laporan-laporan resmi, serta observasi langsung terhadap kebijakan dan kondisi faktual perguruan tinggi yang diteliti. Untuk mendapatkan data faktual lapangan peneliti menggunakan teknik observasi non partisipan, wawancara mendalam, dan studi dokumentasi.

Lokasi penelitian dipilih tiga perguruan tinggi yang berbeda satatus yaitu Universitas Airlangga berstatus badan hukum berlokasi di Kota Surabaya, Universitas Negeri Malang berstatus badan layanan umum berlokasi di Kota Malang dan Politeknik Negeri Madiun berstatus satuan kerja berlokasi di Kota Madiun. Teknik analisis data menggunakan pendekatan deskriptif kualitatif yaitu permasalahan digambarkan berdasar fakta-fakta yang ada kemudian dihubungkan antara fakta yang satu dengan yang lainnya, kemudian ditarik sebuah simpulan.

\section{HASIL PENELITIAN DAN PEMBAHASAN}

Penetapan status perguruan tinggi mulai dari satuan kerja, badan layanan umum maupun badan hukum merupakan identitas dan simbol kewenangan perguruan tinggi dalam menata dan mengatur lembaganya. Kebijakan otonomi sesungguhnya merupakan produk reformasi keuangan untuk memperbaiki kualitas pendidikan agar pendanaan pendidikan bukan hanya berada pada satu pintu, akan tetapi perguruan tinggi dan masyarakat ikut berpartisipasi dalam persoalan pendidikan. Harapannya pemerintah ikut terbantu dengan kebijakan otonomi sebab beban keuangan bukan menjadi tanggung jawab pemerintah, tetapi menjadi tanggungjawab bersama. Perguruan tinggi diberikan kewenangan mencari income untuk menambah biaya operasionalnya, sedangkan masyarakat 
ikut memberikan sumbangan pendidikan sebagai bentuk partisipasi dalam bidang pendidikan.

\section{Arah Kebijakan Otonomi}

Kebijakan otonomi pertama kali muncul bertujuan untuk mereformasi sistem pendidikan tinggi. Kebijakan reformasi dilakukan secara besar-besaran pasca jatuhnya orde baru. Tak terkecuali otonomi perguruan tinggi menjadi prioritas agenda reformasi untuk dilaksanakan. Walaupun kebijakan otonomi sudah digulirkan pasca Indonesia masuk menjadi anggota WTO tahun 1994, tetapi kebijakan otonomi ini belum terlalu familiar karena masih terkendala dengan kebijakan pemerintah yang sifatnya cenderung sentralistik. Inti utama reformasi pendidikan tersebut mencakup reformasi paradigma pendidikan tinggi nasional dan desentralisasi sistem pendidikan nasional dalam rangka relevansi dan perbaikan kualitas.

Kebijakan ini muncul sesungguhnya untuk mereduksi atau mengurangi campur tangan pemerintah dalam penyelenggaraan pendidikan. Hal ini agar sejalan dengan kebijakan WTO yang menuntut untuk meliberalisasi sektor pendidikan. Alasan yang mendasar adalah jika campur tangan pemerintah berkurang akan menumbuhkan otonomi, serta kemandirian lembaga-lembaga pendidikan terutama pendidikan tinggi. Logika tersebut menjadi argumentasi pemerintah untuk tidak mencampuri urusan pendidikan lebih banyak akan tetapi urusan pendidikan diserahkan kepada publik. Jika pemerintah mengurangi campur tangan dalam penyelenggaraan pendidikan justru hal ini akan berdampak kepada masyarakat bahkan dampaknya lebih buruk karena pendidikan tidak lagi ditempatkan sebagai hak dasar bagi setiap warga negara dan negara wajib memenuhinya akan tetapi pendidikan justru menjadi barang komoditas. (Ball, 2016; Tilaar, 2012) menjelaskan bahwa Neoliberalisme sudah merangsek dalam pendidikan nasional. Sadar atau tidak, pendidikan nasional sejak era reformasi sedang menuju pada neoliberalisme. Salahsatu tandanya adalah adanya kecenderungan dari berbagai kebijakan pemerintah untuk mengurangi campur tangan dalam membangun dunia pendidikan. Dimana paham neoliberalisme memberikan kesempatan kepada personal/individu untuk bersaing dan berkreasi serta membiayai segala kebutuhan mereka sendiri. Kondisi ini sangat bertentangan dengan amanat Undang-Undang Dasar 1945 yang memberikan tanggungjawab kepada pemerintah untuk mengalokasikan dana sekurang-kurangnya $20 \%$ dari anggaran pendapatan belanja negara/anggaran pendapatan belanja daerah untuk pembangunan pendidikan tetapi dipihak lain paham neoliberalisme menekankan bahwa campur tangan pemerintah dalam kegiatan pendidikan harus dikurangai.

Ketika kebijakan otonomi ini muncul, justru menjadi sebuah euforia bagi perguruan tinggi. Perguruan tinggi meminta untuk diberikan kebebasan dalam mengurus dan mengelola lembaganya secara independent agar tidak membebani pemerintah. Hal mendasar yang menjadi alasan fundamental bagi perguruan tinggi adalah karena terlalu berbelit-belitnya birokrasi pemerintah untuk memenuhi kebutuhan yang diperlukan perguruan tinggi untuk 
mewujudkan tridaharama perguruan tinggi. Alasan tersebut menjadi pemicu ataupun pemantik untuk melepaskan intervensi pemerintah dalam penyelenggaraan pendidikan tinggi dan pengelolaan pendidikan tinggi diserahkan kepada publik. Hal ini sesungguhnya bukanlah tanpa alasan karena kebijakan otonomi ini adalah kebijakan bersama antara pemerintah dan perguruan tinggi. Kebijakan ini merupakan program yang dicetuskan oleh lembaga-lembaga dunia terutama IMF dan WTO yang ditujukan kepada pemerintah dan perguruan tinggi menjadi eksekutor dalam mewujudkan niat sesungguhnya dari kebijakan ini. Jika dicermati, kebijakan ini sesungguhnya untuk melepaskan peran negara dalam mengatur urusan pendidikan dan pendidikan diserahkan keranah publik untuk mengelola lembaga pendidikan. Untuk memuluskan agenda tersebut pemerintah menggunakan tangan-tangan akademisi dan birokrasi perguruan tinggi untuk mengkampanyekan kebijakan otonomi tersebut dan akademisi maupun para birokrasi perguruan tinggi pun mengamininya. Apa yang menjadi alasan perguruan tinggi menerima kebijakan otonomi perguruan tinggi tersebut. Alasan utamanya adalah agar pengelolaan perguruan tinggi disejajarkan dengan pengelolaan perguruan tinggi yang berada di Amerika dan Eropa. Padahal sesungguhnya kebijakan pendidikan di Amerika dan Eropa merupakan hasil liberalisasi yang dicetuskan WTO dan juga IMF. Tujuannya untuk mengurangi peran negara sebagai penyelenggara pendidikan, sedangkan urusan pendidikan diserahkan kesektor publik. Untuk mengurangi peran negara, perguruan tinggi diberikan kebebasan untuk berkompetisi secara sehat untuk membangun lembaganya. (Tilaar, 2012) menjelaskan bahwa dalam kebijakan otonomi prinsip yang digunakan adalah bagaimana berkompetisi dan bersaing dengan negara-negara lain padahal prinsip kompetisi dan daya saing merupakan konsep yang lahir dari neoliberalisme yang digunakan Bank Dunia/IMF padahal konsep ini oleh pakar ekonomi barat telah divonis sebagai suatu kegagalan, sebab prinsip persaingan sebenarnya merupakan alat kapitalisme untuk kepentingan negara-negara maju.

Lahirnya konsep Universitas Kelas Dunia yang mengarahkan perguruan tinggi untuk bersikap mandiri dan berkompetisi dipasaran. Padahal konsep Universitas Kelas Dunia sesungguhnya merupakan konsep privatisasi untuk menjadikan perguruan tinggi mengikuti arus globalisasi, sedangkan globalisasi sendiri merupakan misi yang diemban IMF, Bank Dunia, maupun WTO dengan tujuan mensejajarkan pembangunan pendidikan secara global, sehingga untuk membangun dunia pendidikan disetiap negara harus mengikuti kebijakan aturan yang ditawarkan lembaga-lembaga dunia tersebut. Dampaknya pendidikan harus mengikuti selera pasar dan diserahkan kepada publik untuk dikelola berdasarkan prinsip kepemilikan publik, sehingga masyarakat menjadi pemilik saham terbesar dalam memberikan kontribusi untuk pendidikan dan pemerintah melepaskan diri dari urusan tersebut. (Ghosh, 2018; H. J. Levin, 1987; J. S. Levin, 2005) mengemukakan bahwa pendidikan tinggi yang pengelolaannya terlepas dari kontrol pemerintah, baik tujuannya mencari profit atau tidak, privatisasilah yang menjadi refleksi dalam merumuskan dan menetapkan berbagai kebijakan pendidikan. Universitas diberi otonomi penuh untuk mengelola sumber dayanya 
seiring intervensi pemerintah yang semakin minim. Kondisi ini berimplikasi pada keharusan universitas untuk mengelola pendanaannya sendiri. Harapannya adalah porsi ketergantungan universitas pada anggaran pemerintah menjadi lebih berkurang. Pendidikan tinggi sebagai sebuah komoditas perlu menghidupi dirinya sendiri.

Ketika otonomi mulai digulirkan masih banyak terjadi perdebatan dikalangan pemerintah, masyarakat maupun dikalangan akademisi. Harapan semua pihak bahwa dengan kebijakan otonomi akan memberikan solusi, justru dengan kebijakan otonomi bahkan memunculkan masalah baru bagi perguruan tinggi negeri. Perguruan tinggi bukan hanya dituntut untuk menjalankan tugasnya dalam mendidik akan tetapi dibebani dengan beban dan tanggung jawab lain yaitu mencari pendanaan sendiri dan membangun partnership untuk mendatangkan income.

Kebijakan otonomi di perguruan tinggi awal mulanya dinilai sebagai sebuah solusi yang ditawarkan pemerintah. Pemerintah berpandangan bahwa dengan kebijakan otonomi akan memberikan solusi dalam pengelolaan pendidikan agar pendidikan dapat dikelola secara baik. Kebijakan otonomi merupakan angin segar bagi perguruan tinggi dengan harapan perguruan tinggi diberikan kewenangan untuk mengelola perguruan tingginya secara mandiri. Akan tetapi setelah dilaksanakan justru kebijakan otonomi mendapatkan perlawanan. Kenyataan ini sebagaimana menimpa Undang-Undang Badan Hukum Pendidikan. Undang-Undang Badan Hukum Pendidikan kemudian dibatalkan mahkamah konstitusi karena melanggar konstitusi negara. Kemudian muncul dalam kebijakan lain yaitu berupa Undang-Undang Nomor 12 Tahun 2012 tentang Pendidikan Tinggi. Walaupun muatan konten yang terkandung didalamnya tidak jauh berbeda dengan Undang-Undang Badan Hukum Pendidikan, tetapi Undang-Undang Pendidikan Tinggi tetap dilegalisasi untuk menutupi kekosongan hukum yang melegitimasi pengelolaan perguruan tinggi.

Otonomi merupakan sebuah keniscayaan yang harus diterima, walaupun pada prakteknya masih terjadi tambal sulam disana sini, tetapi kebijakan otonomi dianggap sebuah solusi akhir. (Zainuddin, 2008) mengemukakan bahwa otonomi bukanlah "obat mujarab" yang dapat menyembuhkan permasalahan pendidikan yang ada sekarang. Justru penerapan konsep otonomi masih mengalami kendala dan permasalahan dalam implementasinya. Jika menelaah lebih jauh bahwa otonomi perguruan tinggi dapat mengarah pada: Pertama, adanya inkoordinasi, dimana perguruan tinggi tidak mau lagi diatur dan dikendalikan oleh pemerintah dalam hal ini menteri pendidikan dan kebudayaan dan mereka lebih memilih untuk mengatur sendiri lembaganya. Kedua, adanya sikap arogansi dari para akademisi untuk memanfaatkan kesempatan dalam memperebutkan kekuasaan dan harta. Ketiga, munculnya paham lebih mementingkan kepentingan kampus masing-masing dengan alasan kompetisi. Keempat, adanya pemisahan teritori antara masyarakat dan dunia kampus. Kelima, perguruan tinggi cenderung melakukan eksploitasi terhadap mahasiswa dalam meningkatkan kapabilitas perguruan tinggi bersangkutan. 
Kebijakan otonomi masih menjadi sebuah perdebatan karena belum diketahui arahnya dan masih menjadi polemik dikalangan masyarakat, akademisi maupun praktisi pendidikan. Disatu sisi arah dari kebijakan otonomi dinilai untuk melepaskan peran serta tanggung jawab pemerintah dalam penyelenggaraan pendidikan dan pendidikan diserahkan kepada masyarakat dan perguruan tinggi untuk mengelolannya. Akan tetapi disisi lain pemerintah berargumen bahwa kebijakan otonomi ini memiliki tujuan untuk membangun dunia pendidikan agar dalam pengelolaannya dapat dikelola dengan baik, transparan, akuntabel, dan berkeadilan. Banyak kalangan menilai kebijakan otonomi mengurangi peran pemerintah sebagai pemegang saham terbesar dalam pennyelenggaraan pendidikan. Justru pengelolaan pendidikan akan berbalik arah menjadi tanggung jawab masyarakat beserta perguruan tinggi.

\section{Otonomi Lembaga Perguruan Tinggi}

Undang-Undang Nomor 20 Tahun 2003 tentang Sistem Pendidikan Nasional dan Undang-Undang Nomor 12 Tahun 2012 tentang Pendidikan Tinggi, merupakan dasar legalitas untuk melegitimasi perguruan tinggi agar pengelolaannya diatur secara otonomi. Dengan dasar hukum tersebut perguruan tinggi diberikan opsi untuk merubah statusnya menjadi Badan Hukum atau Badan Layanan Umum. Hal ini sebagaiman dijelaskan dalam Undang-Undang Nomor 12 Tahun 2012 pada pasal 65 ayat 1 menjelaskan bahwa perguruan tinggi negeri dapat menerapkan pola pengelolaan keuangan badan layanan umum atau dengan membentuk perguruan tinggi negeri badan hukum untuk menghasilkan pendidikan tinggi bermutu. Dari penjelasan Undang-Undang tersebut sesungguhnya kontennya merupakan sebuah instruksi tentang mekanisme pengelolaan keuangan lembaga perguruan tinggi, tetapi statusnya juga melekat pada lembaga atau institusinya. (Darmaningtyas, 2015) menyatakan bahwa otonomi dengan perubahan Perguruan Tinggi Badan Hukum dan Badan Layanan Umum dapat dikatakan bahwa kebijakan ini melahirkan stratifikasi perguruan tinggi. Pembagiannya didasarkan pada sumber pembiayaan, dimana yang sudah mapan secara ekonomi diberikan kemandirian, ketika belum mapan secara ekonomi maka pemerintah mengontrolnya dengan harapan agar sedikit demi sedikit dapat berkembang secara mandiri.

Fakta tersebut sebagaimana dijelaskan dalam Undang-Undang Nomor 12 Tahun 2012 tentang Pendidikan Tinggi pada pasal 62 ayat 1 sampai ayat 4 . Didalamnya dijelaskan bahwa perguruan tinggi memiliki otonomi untuk mengelola sendiri lembaganya dan dasar serta tujuan pengelolaannya disesuaikan dengan kemampuan perguruan tinggi dan diatur dengan peraturan menteri. Fakta menunjukan bahwa pemerintah tidak mampu membiayai pendidikan nasional, khususnya pendidikan tinggi. Dimana sebelum ditetapkannya kebijakan otonomi secara masif lembaga perguruan tinggi mendapatkan subsidi dari pemerintah sekitar $75 \%$. Artinya bahwa pemerintah memberikan porsi lebih besar untuk membiayai biaya operasional perguruan tinggi, sedangkan sisanya $25 \%$ berasal dari masyarakat termasuk didalamnya dana Uang Kuliah Tunggal. Namun pemerintah mencabut subsidi dan 
memberikan otonomi kepada lembaga perguruan tinggi untuk mengelola perguruan tingginya secara mandiri. Kemandirian ini memiliki maksud bahwa perguruan tinggi diberikan otonomi untuk mencari pendanaan dan mengelola keuangan masing-masing. Kebijakan otonomi telah merubah paradigma pengelolaan perguruan tinggi yang sebelumnya merupakan tanggung jawab pemerintah kemudian berubah menjadi tanggung jawab masyarakat dan juga perguruan tinggi dengan porsi yang berbeda. Hal ini sebagaimana disampaikan Dirjen Sumber Daya Iptek Kemenristekdikti Prof. Dr. Ali Gufron Mukti, bahwa sebuah perguruan tinggi dikatakan ideal apabila pengelolaan dana dengan komposisi $40 \%$ dari negara, 30\% dari uang kuliah mahasiswa, dan 30\% sisanya pengembangan produk (holding), (Jawa Pos, 2016).

Perubahan proporsi persentase tersebut menunjukkan bahwa pemerintah melepas tanggung jawab dalam penyelenggaraan pendidikan dan pendidikan diserahkan kepada masyarakat dan juga perguruan tinggi untuk membiayainya. Perguruan tinggi kemudian diberi beban untuk mencari pendanaan sendiri. Perguruan tinggi melakukan berbagai macam upaya untuk mendapatkan dana sebagai pemasukan income generity. Upaya tersebut mulai dari mengkomersilkan infrastruktur yang dimiliki, membangun usaha-usaha bisnis yang potensial bahkan membangun partnership untuk mendukung pemasukan income generity bagi perguruan tinggi. Apabila perguruan tinggi tidak memiliki usaha maupun infrastruktur yang dikomersilkan opsi yang dilakukan adalah menaikkan Uang Kuliah Tunggal mahasiswa.

Disamping itu perguruan tinggi juga memiliki kewenangan untuk menentukan tarif biaya setiap jurusan untuk masing-masing program studi yang diprogram mahasiswa baik eksakta maupun non eksakta. Tarif biaya yang ditentukan juga berfariasi tergantung kepada pendapatan yang dimiliki orang tua mahasiswa. Hal ini menunjukan bahwa perguruan tinggi sebagai lembaga akademik justru dikelola seperti lembaga korporasi atau perusahaan. Perguruan tinggi sebagai lembaga pendidikan dikelola seperti lembaga bisnis yang mirip dengan MALL. Fakta ini menunjukan bahwa ada indikasi MALLISASI perguruan tinggi dalam pengelolaannya karena setiap orang yang masuk disuguhkan dengan berbagai tarif yang harus dibayarkan mahasiswa. Kecenderungan lembaga perguruan tinggi diibaratkan seperti perusahaan yang mencari dana untuk membiayai karyawan dan membiayai biaya operasional yang dibutuhkan lembaga tersebut. Ketika dana yang dimiliki perguruan tinggi sangat minim maka mahasiswa menjadi ladang eksploitasi. Fakta menunjukkan bahwa perguruan tinggi masih menggali dana dari Uang Kuliah Tunggal mahasiswa. Sedangkan subsidi dari pemerintah sudah mulai dikurangi. Kondisi ini disebabkan karena banyak kalangan menilai ketika subsidi pendidikan diberikan akan mengurangi jumlah pemasukan yang bersumber dari mahasiswa. Artinya bahwa jika sumber pemasukan dari mahasiswa jumlahnya sedikit mengakibatkan inefisiensi pengelolaan sumberdaya perguruan tinggi. Dari kalangan pemerintah maupun perguruan tinggi menilai bahwa pemberlakuan subsidi ditingkat perguruan tinggi yang ditanggung pemerintah dianggap sebagai bentuk inefisiensi sehingga perlu adanya subsidi silang. 
Resep kebijakan subsidi silang diperguruan tinggi hadir dalam bentuk wajah kebijakan Uang Kuliah Tunggal. Uang Kuliah Tunggal merupakan biaya kebutuhan yang harus dibayarkan setiap mahasiswa selama menempuh pendidikan di perguruan tinggi dan biaya-biaya tersebut dibayarkan persemesternya. Uang Kuliah Tunggal merupakan akumulasi yang dibayarkan mahasiswa termasuk di dalamnya gaji dosen, fasilitas belajar, pemeliharaan atau perawatan gedung, biaya listrik dan sebagainya. Walaupun Uang Kuliah Tunggal yang dibayarkan disesuaikan dengan tingkat pendapatan orang tua mahasiswa, tetapi Uang Kuliah Tunggal selalu mengalami penyesuaian setiap tahunnya dan berpotensi terus mengalami kenaikkan. Disamping itu belum ada aturan yang mengatur kebijakan angka maksimal mengenai besaran porsi pendanaan universitas yang didapat dari akumulasi biaya pendidikan yang ditanggung mahasiswa, sehingga kondisi ini merupakan celah bagi perguruan tinggi untuk mengeruk pos pendanaan dari mahasiswa.

Selama ini paradigma yang dibangun perguruan tinggi dan pemerintah adalah jika perguruan tinggi diberikan otonomi baik akademik maupun non akademik maka perguruan tinggi bisa mengelola diri sendiri secara mandiri. Perguruan tinggi memiliki kewenangan untuk membuat keputusan dan mengambil kebijakan sendiri. Keberadaan pemerintah hanya mengawasi ramburambu yang berlaku. Sedangkan yang menyangkut untuk urusan pembiayaan pendidikan pemerintah masih tetap memberikan akan tetapi dengan asumsi sebagian lagi perguruan tinggi bisa mencari sendiri. Target dari kebijakan otonomi adalah efisiensi pengelolaan perguruan tinggi negeri. Artinya bahwa jika perguruan tinggi memiliki kewenangan secara kelembagaan maka dapat berbuat banyak untuk meningkatkan mutu. Maka perubahan status perguruan tinggi dari satuan kerja menjadi badan layanan umum, badan layanan umum menjadi badan hukum sesungguhnya merupakan bentuk atau upaya yang dilakukan perguruan tinggi untuk mengelola perguruan tinggi tersebut secara mandiri. Jika perguruan tinggi diberikan kewenangan secara luas harapannya agar perguruan tinggi dapat menentukan kebijakan sendiri dan menentukan besaran biaya sendiri sehingga keberadaan perguruan tinggi menjadi independen dan desentralistik. Jika hal ini terjadi dikhawatirkan akan muncul raja-raja baru di perguruan tinggi yang memiliki otoritas sendiri sehingga dengan kewenangan tersebut perguruan tinggi akan leluasa menentukan dan menetapkan kebijakan berdasarkan kemauan sendiri yang dapat memberatkan masyarakat untuk melanjutkan pendidikan kejenjang perguruan tinggi. Tetapi saat ini kebijakan otonomi adalah sebuah keniscayaan bagi perguruan tinggi dan merupakan pilihan yang harus dipilih untuk meningkatkan efisiensi dalam meningkatkan mutu pendidikan. Walaupun perguruan tinggi dan masyarakat menjadi korban dari kebijakan otonomi tetapi kebijakan ini harus tetap digulirkan sebagai konsekuensi keikutsertaan negara menjadi anggota WTO.

Sejak digulirkan otonomi di perguruan tinggi, isu yang paling fenomenal adalah mengenai kemandirian dalam mencari pendanaan. Perguruan tinggi dituntut untuk menghidupi sendiri lembaganya tanpa mengharapkan bantuan secara langsung dari pemerintah. Perguruan tinggi kemudian mengambil langkah 
antisipasi untuk mengatasi kebijakan tersebut. Langkah-langkah ini kemudian dituangkan dalam garis-garis besar anggaran yang dibutuhkan dan perguruan tinggi mulai mencari cara untuk mendapatkan income generity untuk mendanai lembaganya. Pemerintah hanya mengawal melalui kebijakan sketsa UndangUndang sebagai payung hukum untuk menjustifikasi maupun melegalisasi kebijakan yang dilakukan perguruan tinggi.

Perguruan tinggi akhirnya banyak membangun partnership dengan lembaga-lembaga lain, membangun tempat-tempat atau usaha bisnis, menarik Uang Kuliah Tunggal dari mahasiswa dan usaha-usaha lain yang dapat menghasilkan income generity. Konsep awal kebijakan otonomi adalah untuk meningkatkan kualitas pendidikan justru terkendala dengan dana. Pada akhirnya perguruan tinggi harus menjadikan masyarakat sebagai eksperimen untuk menghasilkan dana. (Rahardjo, 2010) mengemukakan bahwa tujuan otonomi perguruan tinggi untuk meningkatkan kualitas pendidikan melalui kemandirian, tetapi kemandirian ini dipakai sebagai dasar untuk menghimpun dana dari masyarakat semaunya.

Kebijakan liberalisasi pendidikan terus dimunculkan dan dilakukan dengan berbagaimacam cara. Salah satunya adalah dengan membuat regulasi yang melahirkan produk perundang-undangan diantaranya Undang-Undang Nomor 25 Tahun 2007 tentang Penanaman Modal. Undang-Undang ini justru memiliki implikasi terhadap pengelolaan pendidikan. Undang-Undang ini lahir semestinya untuk mengatur kegiatan bisnis tetapi pada akhirnya produk turunannya juga menyasar ke sektor pendidikan. Lahirnya Keputusan Presiden Nomor 44 Tahun 2016 yang merupakan produk beberapa revisi keputusan presiden tentang daftar bidang usaha yang tertutup dan bidang usaha yang terbuka dengan persyaratan di bidang penananman modal yang dalam lampirannya disebutkan bahwa pendidikan termasuk pendidikan tinggi merupakan sektor yang terbuka untuk penanaman modal asing dengan besaran prosentase $49 \%$. Hal ini mengisyaratkan bahwa perusahaan boleh menanamkan sahamnya dalam lembaga pendidikan untuk membantu lembaga tersebut dalam mengembangkan perguruan tinggi. Padahal sejatinya sebuah perusahaan atau bidang usaha ketika menanamkan modalnya dalam sebuah lembaga orientasinya mengejar keuntungan. Pemerintah telah memberi ruang kepada para pemodal untuk membantu perguruan tinggi melalui kebijakan Undang-Undang Nomor 12 Tahun 2012 tentang Pendidikan Tinggi pada pasal 79 dan pasal 86, dimana dalam pasal ini menjelaskan bahwa pemerintah memfasilitasi dunia usaha, dunia industri ataupun pihak lain untuk melakukan kerjasama maupun yang memberikan bantuan dana kepada perguruan tinggi.

\section{Pendanaan Perguruan Tinggi}

Semenjak munculnya kebijakan otonomi di perguruan tinggi paradigma pendanaan perguruan tinggi juga berubah. Ketika otonomi digulirkan harapan perguruan tinggi adalah diberikan kewenangan untuk mengatur perguruan tinggi tersebut secara desentralistik akan tetapi secara faktual kebijakan otonomi hanya diberikan sebatas pada pencarian dana dan pengelolaan keuangan. 
(Zainuddin, 2008) mengemukakan bahwa sentralisasi dan desentralisasi pendidikan seolah-olah tidak ada bedanya, bahkan semakin membebani masyarakat. Disaat masyarakat membutuhkan suatu pendidikan yang memadai, disaat itu pula masyarakat harus dicekik oleh tingginya biaya pendidikan, sehingga bagi masyarakat miskin biaya pendidikan yang mahal merupakan penindasan yang amat pedih.

Perguruan tinggi di indonesia menghadapi masalah pembiayaan yang lebih serius. Kondisi ini diperparah dengan sikap dan prilaku pejabat negara yang korup yang dapat mempengaruhi pengelolaan kebijakan politik pembiayaan pendidikan. (Triharso, 2015) menyatakan bahwa birokrasi pemerintah ternyata terjangkiti virus ganas korupsi, kolusi dan nepotisme. Lebih ironis lagi, perguruan tinggi terutama perguruan tinggi negeri juga tidak kuasa menghadapi kondisi bangsa yang demikian dan bahkan cenderung terbawa arus gelombang kekacauan ini.

Pembiayaan perguruan tinggi masih jauh dari kata memuaskan apalagi tidak didukung dengan infrastruktur kelembagaan dan sumber daya manusia yang cukup kuat. Karena kondisi keuangan negara yang tidak kuat maka paradigma pengelolaan perguruan tinggi terutama dalam hal pembiayaan mulai bergeser. Masyarakat dan mahasiswa mulai dilirik dan dibebani dengan berbagai tanggung jawab dalam hal pendanaan. Pemerintah pun mengalokasikan untuk biaya pendidikan relatif semakin kecil. Konsekuensinya adalah pemerintah menetapkan kebijakan fiskal untuk mengurangi anggaran yang dikeluarkan pemerintah. Subsidi untuk perguruan tinggi negeri berkurang atau tetap. Akan tetapi perguruan tinggi dituntut untuk meningkatkan kualitas dan pelayanan kepada mahasiswa. Akibatnya perguruan tinggi negeri yang bersangkutan memobilisasi pencarian dana dari banyak sumber dan salah satunya yang paling mudah adalah dari mahasiswa. (Zainuddin, 2008) menjelakan bahwa selama ini orang tua mahasiswa, cenderung hanya sebagai "target pasar" dari pendidikan.

Pencarian dana bertujuan untuk menghasilkan Penerimaan Negara Bukan

Pajak. Penerimaan Negara Bukan Pajak dimanfaatkan untuk pembiayaan operasional perguruan tinggi. Selama ini Penerimaan Negara Bukan Pajak perguruan tinggi negeri didapatkan dari sumbangan pembinaan pendidikan, biaya seleksi ujian masuk Perguruan Tinggi Negeri, hasil penjualan dari penyelenggaraan pendidikan tinggi, hasil kontrak kerja sesuai peran dan fungsi perguruan tinggi, serta sumbangan atau hibah perorangan, lembaga pemerintah dan non pemerintah serta penerimaan dari masyarakat. Perguruan tinggi justru dituding menjadi lembaga yang mengkomersialisasi pendidikan karena menarik biaya cukup tinggi. (Rahardjo, 2010) mengemukakan bahwa otonomi dapat menjadikan perguruan tinggi semakin komersil dan program studi tertentu hanya bisa dijangkau oleh yang berduit. Hal ini terbukti bahwa beberapa perguruan tinggi menarik biaya yang sangat tinggi untuk program studi tertentu. Akibatnya yang bisa masuk ke program studi tersebut hanya mereka yang punya uang tebal. Masyarakat kelas bawah sulit untuk menjangkaunya, sehingga pendidikan hanya untuk kaum the have. 


\section{Dampak Kebijakan Otonomi}

Biaya untuk masuk pendidikan tinggi dari hari kehari semakin tidak terjangkau. Kebutuhan untuk melakukan perbaikan terhadap sistem pendidikan harus dihadapkan dengan penyediaan dana dari Anggaran Pendapatan Belanja Negara untuk pendidikan terkhusus pendidikan tinggi sangat terbatas. Kecenderungan negara melepas tanggung jawab dalam membiayai pendidikan tinggi telah menimbulkan dampak yang makin besar dimana orang miskin semakin sulit untuk mengakses pendidikan tinggi karena mereka tidak mampu menjangkau untuk membayar uang masuk ataupun uang semesteran karena semakin mahal. Walaupun pemerintah mengalokasikan $20 \%$ dari kalangan orang miskin sesuai dengan amanat Undang-Undang Nomor 12 tahun 2012 tentang Pendidikan Tinggi dengan program bidikmisi, tetapi program ini tidak dapat memenuhi kuota yang diberikan. $20 \%$ itupun batas kuota minimum dan dikhawatirkan perguruan tinggi negeri memenuhi batas minimum tersebut. Disamping itu kebijakan 20\%, juga merupakan sebuah bentuk diskriminasi bagi masyarakat. Mengapa orang miskin hanya diberikan kuota $20 \%$ mengapa tidak $50 \%$. Siapa yang $80 \%$ nya itu. Mereka dari golongan orang-orang yang mampu membayar secara finansial, sehingga pada akhirnya perguruan tinggi hanya bisa menampung mahasiswa dari kalangan orang-orang kaya saja.

Jumlah orang miskin yang tergolong tidak mampu semakin kecil untuk masuk ke perguruan tinggi sedangkan jumlah golongan orang kaya semakin besar dan semakin mendominasi. Seharusnya negara memiliki tugas untuk memfasilitasi semua warga negarnya agar mereka dapat menempuh pendidikan sampai kejenjang perguruan tinggi dengan biaya yang terjangkau tanpa adanya diskriminasi. Bukan membuat regulasi yang justru menyebabkan pelayanan pendidikan tinggi tidak terjangkau oleh masyarakat luas. Hal ini senada dengan pernyataan (Triharso, 2015) bahwa perguruan tinggi harus menghasilkan kepandaian kolektif bukan kepandaian parsial. Kebijakan pemerintah hanya memprioritaskan warga masyarakat yang memiliki modal yang sangat kuat sedangkan warga miskin yang tidak mampu mulai terpinggirkan. Hal yang menarik untuk direnungkan adalah bahwa pemerintah mengeluarkan kebijakan $20 \%$ bagi warga yang tidak mampu terutama dari wilayah yang memiliki kriteria terluar dan tertinggal, lebih diprioritaskan diterima di perguruan tinggi. Mengapa $20 \%$ saja mengapa tidak 50\%. Ini artinya bahwa orang miskin dilarang untuk sekolah. Yang terjadi adalah munculnya Perguruan Tinggi Negeri dengan tarif pendidikan yang semakin besar yang tidak dapat diakses kalangan orang miskin. Pada akhirnya Perguruan Tinggi Negeri tersebut hanya mereproduksi kelas elit yang eksklusif disatu sisi dan mereproduksi kemiskinan disisi lain. Pada akhirnya melahirkan kesenjangan yang sangat besar antara orang kaya dan orang miskin. Yang kaya dapat mengakses pendidikan di perguruan tinggi karena didukung dengan finansial yang memadai sedangkan dari kalangan orang miskin semakin sulit untuk menjangkau perguruan tinggi yang bermutu karena kurangnya dukungan finansial. Padahal sejatinya keberadaan pendidikan ada untuk memperpendek atau menghilangakan jurang ketidak adilan ditengah-tengah masyarakat sehingga tidak akan menciptakan disintegrasi sosial. 
Di sisi lain kebijakan otonomi justru mengebiri peran pemerintah dan pemerintah berfungsi sebagai regulator saja. Dengan paradigma tersebut akan berpengaruh terhadap pengelolaan pendidikan. Boleh jadi dengan kebijakan otonomi akan memunculkan berbagai asumsi bahwa kebijakan otonomi akan mengurangi beban pemerintah dalam pembiayaan pendidikan sehingga anggaran yang dimiliki dapat dimanfaatkan pada pos lain yang lebih mendesak. Disamping itu masyarakat diberikan peluang yang sangat besar untuk ikut berpartisipasi dalam mencerdaskan kehidupan bangsa, sedangkan perguruan tinggi akan semakin lebih kompetitif dalam meningkatkan fasilitas dan mutu pendidikan. Tetapi jika pemerintah berlepas diri akan mendistorsi peran pemerintah sehingga membawa dampak sosial. Dampak yang bisa ditimbulkan adalah banyaknya pungutan yang dilakukan lembaga pendidikan sebab beban pemerintah untuk membiayai pendidikan semakin berkurang. Hal ini mengakibatkan pendidikan menjadi mahal sebab dengan biaya pendidikan yang tinggi serta banyaknya biaya atau sumbangan pendidikan yang diberlakukan lembaga pendidikan maka secara tidak langsung memberikan keuntungan serta menambah income untuk pemasukan kas lembaga pendidikan. Pendidikan menjadi barang mewah karena semakin sulit untuk dijangkau kalangan kurang mampu sehingga meningkatkan angka putus sekolah yang juga berdampak pada peningkatan pengangguran, tindakan kriminalitas, pekerja anak maupun anak jalanan.

Dunia pendidikan menjadi lahan bisnis yang trend. Pendidikan diibaratkan mall atau pasar yang menyediakan berbagaimacam barang yang dibutuhkan para konsumen, sedangkan para pendidik sebagai kasir yang bertugas melayani peserta didik sebagai pelanggan. Hal ini justru menciptakan gap atau jurang pemisah dalam mengakases pendidikan. Pendidikan justru menciptakan polarisasi dalam masyarakat antara masyarakat mampu dan tidak mampu. Disamping itu lembaga pendidikan juga menjadi terpetakan antara lembaga pendidikan yang unggul dan tidak unggul sehingga menciptakan stigmatisasi dan segregasi kelas sosial antara kaya dan miskin. Dampaknya adalah terjadi pelabelan sosial dikalangan masyarakat bahwa perguruan tinggi ternama adalah milik orang dari kalangan kelas sosial tinggi, sedangkan perguruan tinggi sederhana tempat berkumpulnya masyarakat dari kalangan masyarakat kelas sosial rendah. Sehingga masyarakat dari kalangan ekonomi rendah harus menerima kenyataan untuk menjadi warga kelas dua karena sumbangan pendidikan yang tidak terjangkau. Konsekuensinya, terjadi diskriminasi dalam memperoleh pendidikan yang layak.

Berdasarkan fakta temuan diatas dapat dirumuskan poin-poin yang menjadi garis besar dari penjelasan secara umum perbedaan ketiga situs penelitian yang akan dijelaskan pada Tabel 1. 
Tabel 1 Perbedaan Kondisi Perguruan Tinggi Berdasarkan Status Lembaga

\begin{tabular}{|c|c|c|c|c|}
\hline No & Uraian & Universitas Airlangga & $\begin{array}{l}\text { Universitas Negeri } \\
\text { Malang }\end{array}$ & $\begin{array}{l}\text { Politeknik Negeri } \\
\text { Madiun }\end{array}$ \\
\hline 1 & Status lembaga & Badan Hukum (BH) & BLU/PPKBLU & Satuan Kerja (SATKER) \\
\hline 2 & $\begin{array}{l}\text { Penetapan } \\
\text { status lembaga }\end{array}$ & $\begin{array}{l}\text { Ditetapkan melalui } \\
\text { Peraturan Pemerintah }\end{array}$ & $\begin{array}{l}\text { Ditetapkan melalui } \\
\text { Keputusan Menteri } \\
\text { Keuangan RI atas usul } \\
\text { oleh Kemenristekdikti }\end{array}$ & $\begin{array}{l}\text { Ditetapkan melalui } \\
\text { Keputusan Menteri } \\
\text { Pendidikan dan } \\
\text { Kebudayaan. }\end{array}$ \\
\hline 3 & $\begin{array}{l}\text { Orientasi arah } \\
\text { perguruan } \\
\text { tinggi jangka } \\
\text { panjang }\end{array}$ & $\begin{array}{l}\text { Menuju World Class } \\
\text { University (WCU) }\end{array}$ & $\begin{array}{l}\text { Menuju Perguruan } \\
\text { Tinggi Negeri Badan } \\
\text { Hukum (PTNBH) }\end{array}$ & $\begin{array}{l}\text { Menuju Perguruan } \\
\text { Tinggi Negeri Badan } \\
\text { Layanan Umum } \\
\text { (PTNBLU) }\end{array}$ \\
\hline 4 & $\begin{array}{l}\text { Status Otonomi } \\
\text { Akademik/Non } \\
\text { Akademik }\end{array}$ & $\begin{array}{l}\text { Diberikan otonomi } \\
\text { akademik dan non } \\
\text { akademik }\end{array}$ & $\begin{array}{l}\text { Diberikan otonomi } \\
\text { akademik dan non } \\
\text { akademik }\end{array}$ & $\begin{array}{l}\text { Hanya diberikan } \\
\text { otonomi akademik }\end{array}$ \\
\hline 5 & $\begin{array}{l}\text { Kewenangan } \\
\text { perguruan } \\
\text { tinggi dalam } \\
\text { menjalankan } \\
\text { otonomi }\end{array}$ & $\begin{array}{l}\text { Diberikan otonomi secara } \\
\text { luas }\end{array}$ & $\begin{array}{l}\text { Diberikan otonomi tetapi } \\
\text { harus seizin pemerintah } \\
\text { dalam menjalankan } \\
\text { renstra perguruan tinggi. }\end{array}$ & $\begin{array}{l}\text { Masih dibawah } \\
\text { kontrol/tanggung } \\
\text { jawab pemerintah. }\end{array}$ \\
\hline 6 & $\begin{array}{l}\text { Kewenangan } \\
\text { Perguruan } \\
\text { tinggi dalam } \\
\text { struktur } \\
\text { otonomi } \\
\text { kelembagaan }\end{array}$ & $\begin{array}{ll}\text { a. } & \text { Diberikan } \\
\text { kewenangan secara } \\
\text { luas untuk } \\
\text { menganngkat } \\
\text { DTT/Dosen non PNS } \\
\text { tanpa seizin } \\
\text { pemerintah. } \\
\text { b. Diberikan } \\
\text { kewenangan untuk } \\
\text { membuka dan } \\
\text { menutup prodi tanpa } \\
\text { izin dari pemerintah. } \\
\text { Diberikan } \\
\text { kewenangan untuk } \\
\text { menggunakan } \\
\text { keuangan secara } \\
\text { mandiri tanpa izin dari } \\
\text { pemerintah }\end{array}$ & $\begin{array}{ll}\text { a. } & \text { Diberikan } \\
\text { kewenangan secara } \\
\text { luas untuk } \\
\text { menganngkat } \\
\text { DTT/Dosen non PNS } \\
\text { tetapi harus seizin } \\
\text { pemerintah. } \\
\text { b. Diberikan } \\
\text { kewenangan untuk } \\
\text { membuka dan } \\
\text { menutup prodi } \\
\text { tetapi harus izin dari } \\
\text { pemerintah. } \\
\text { Diberikan } \\
\text { kewenangan untuk } \\
\text { menggunakan } \\
\text { keuangan secara } \\
\text { mandiri tetapi harus } \\
\text { izin dari pemerintah }\end{array}$ & $\begin{array}{l}\text { Semua masih di bawah } \\
\text { aturan/regulasi yang } \\
\text { ditetapkan oleh } \\
\text { pemerintah }\end{array}$ \\
\hline 7 & $\begin{array}{l}\text { Sumber } \\
\text { pendanaan }\end{array}$ & $\begin{array}{l}\text { Negara, Perguruan Tinggi, } \\
\text { mahasiswa/masyarakat. }\end{array}$ & $\begin{array}{l}\text { Negara, Perguruan } \\
\text { Tinggi, } \\
\text { mahasiswa/masyarakat }\end{array}$ & $\begin{array}{l}\text { Negara, } \\
\text { mahasiswa/masyarakat }\end{array}$ \\
\hline 8 & $\begin{array}{l}\text { Mekanisme } \\
\text { memperoleh } \\
\text { PNBP }\end{array}$ & $\begin{array}{l}\text { Melalui kerjasama, } \\
\text { membuka unit-unit } \\
\text { bisnis/usaha, } \\
\text { mengkomersilkan fasilitas } \\
\text { perguruan tinggi yang } \\
\text { potensial. }\end{array}$ & $\begin{array}{l}\text { Melalui kerjasama, } \\
\text { membuka unit-unit } \\
\text { bisnis/usaha, } \\
\text { mengkomersilkan } \\
\text { fasilitas perguruan tinggi } \\
\text { yang potensial. }\end{array}$ & $\begin{array}{l}\text { Dari negara dan } \\
\text { mahasiswa karena tidak } \\
\text { diberikan kewenangan } \\
\text { untuk membuka unit } \\
\text { usaha/bisnis maupun } \\
\text { yang lainnya. }\end{array}$ \\
\hline 9 & $\begin{array}{l}\text { Pemanfaatan } \\
\text { PNBP }\end{array}$ & $\begin{array}{l}\text { Bebas menggunakan } \\
\text { Anggaran PNBP yang } \\
\text { Dimiliki Perguruan tinggi. }\end{array}$ & $\begin{array}{l}\text { Bebas menggunakan } \\
\text { Anggaran PNBP } \\
\text { Perguruan tinggi akan }\end{array}$ & $\begin{array}{l}\text { Semua tergantung dari } \\
\text { kebijakan dan intruksi } \\
\text { pemerintah. }\end{array}$ \\
\hline
\end{tabular}




\begin{tabular}{|l|l|l|l|}
\hline & & tetapi harus izin dan \\
& penggunaannya harus & \\
sesuai dengan porsi dan & & item tertentu dan harus \\
& ada sisa untuk anggaran & Berikutnya. \\
\hline
\end{tabular}

\section{SIMPULAN}

Sejak awal otonomi diimplementasikan alasan utamanya untuk menciptakan transparansi, akuntabilitas, dalam meningkatkan mutu pengelolaan perguruan tinggi. Tetapi kebijakan otonomi justru menimbulkan persoalan baru. Di masyarakat terjadi prokontra dalam menyikapi kebijakan ini. Masyarakat menilai bahwa kebijakan otonomi merupakan pintu masuk pemerintah untuk melepaskan diri dari tanggung jawab sebagai penyelenggara pendidikan. Dampaknya perguruan tinggi dibebani tugas lebih besar dalam meningkatkan kualitas pendidikan termasuk mencari pendanaan sendiri. Akhirnya masyarakat dijadikan sebagai lahan eksploitasi untuk meningkatkan pemasukan Penerimaan Negara Bukan Pajak perguruan tinggi dengan penetapan berbagai macam tarif biaya pendidikan yang sangat besar. Dengan demikian kebijakan otonomi adalah merupakan jebakan politik pemerintah untuk memprivatisasi perguruan tinggi, sehingga penyelenggaran perguruan tinggi bukan lagi menjadi tanggung jawab pemerintah, tetapi menjadi tanggungjawab perguruan tinggi dan masyarakat.

\section{UCAPAN TERIMAKASIH}

Penulis mengucapkan terimakasih kepada seluruh pihak yang telah banyak membantu dalam penulisan artikel ini. Penulis juga mengucapkan terimakasih kepada editorial JET yang telah menyediakan sarana publikasi bagi kami.

\section{DAFTAR PUSTAKA}

Altbach, P. G., \& Knight, J. (2007). The Internationalization of Higher Education: Motivations and Realities. Journal of Studies in International Education, 11(3), 290-305. https://doi.org/10.1177/1028315307303542

Arifin, I., Juharyanto, Mustiningsih, \& Taufiq, A. (2018). Islamic Crash Course as a Leadership Strategy of School Principals in Strengthening School Organizational Culture. SAGE Open. https://doi.org/10.1177/2158244018799849

Ball, S. J. (2016). Neoliberal education? Confronting the slouching beast. Policy Futures in Education, 14(8), 1046-1059. https://doi.org/10.1177/1478210316664259

Bok, D. (2003). Universities In the Marketplace: The Commercialization of Higher Education. New Jersey: Princeton University Press.

Darmaningtyas. (2014). Melawan Liberalisasi Pendidikan. Malang: Madani.

Darmaningtyas. (2015). Pendidikan yang Memiskinkan. Malang: Intrans Publishing.

Dwiningrum. (2013). Kapitalis Pendidikan vs Pendidikan: Pendekatan Kultural dan 
Modal Sosial dalam Membangun Masyarakat Terdidik. Yogyakarta: AshShaff.

Education, H. (2011). Higher Education : Students at the Heart of the System. In Higher Education.

Fajar, M. (2015). Krisis Politik \& Proposisi Demokratisasi: Perubahan Politik Orde Baru ke Reformasi. Jakarta: Bumi Aksara.

Fiere, P., \& Illich, ivan dkk. (2003). Menggugat Pendidikan. Harian Kompas.

Ghosh, S. (2018). Autonomy for Universities: Goverments Move to Privatise is Eksklusionary. Journal Economic \& Political, 53(13).

Gusnardi. (2014). Pendidikan Anti Korupsi di Perguruan Tinggi: Perlukah? Pekbis.

Hadi, H. (2016). KEBIJAKAN PENDIDIKAN NASIONAL TERHADAP PENDIDIKAN

ISLAM DAN PENDIDIKAN SEKULER. MIQOT: Jurnal IImu-IImu Keislaman. https://doi.org/10.30821/miqot.v40i2.304

Hadi, S. (2004). Strategi Pembangunan Indonesia Pasca IMF. Jakarta: Granit.

Hakim, L. (2012). Model Integrasi Pendidikan Anti Korupsi dalam Kurikulum Pendidikan Islam. Taklim.

Hasbullah, H. M. (2016). Kebijakan Pendidikan: Dalam Perspektif Teori, Aplikasi, dan Kondisi Objektif Pendidikan di Indonesia. Jakarta: PT Raja Grafindo Persada.

Hill, D. (2003). Global Neo-Liberalism, The Deformation of Education and Resistance. The Journal of Critical Education Policy Studies, 1(1).

Icksan, M. A. (1985). Mahasiswa dan Kebebasan Akademik. Yogyakarta: PT Hanindita.

Jawa Pos. (2016). Tak Punya Uang, PTN Bisa Jual Produk. p. 23.

Juharyanto, J., Sultoni, S., Arifin, I., \& Nurabadi, A. (2019). Kepemimpinan Kepala Sekolah dalam Penguatan Peran Multi-Stakeholders Forum (Masalah dan Strategi Solutif Peningkatan Mutu SD - SMP Satu Atap di Daerah Terpencil). Sekolah Dasar: Kajian Teori Dan Praktik Pendidikan. https://doi.org/10.17977/um009v28i12019p001

Karweti, E. (2010). Pengaruh Kemampuan Manajerial Kepala Sekolah Dan Faktor Yang Mempengaruhi Motivasi Kerja Terhadap Kinerja Guru SLB Di Kabupaten Subang. Journal Penelitian Pendidikan.

Levin, H. J. (1987). Education as a Public and a Private Good. Journal of Policy and Management, 6(4), 628-641.

Levin, J. S. (2005). The Business Culture of the Community College: Students as Consumers; Students as Commodities. New Directions for Higher Education, 129(1), 11-26.

Lorig, K. R., \& Holman, H. R. (2003). Self-management education: History, definition, outcomes, and mechanisms. Annals of Behavioral Medicine. https://doi.org/10.1207/S15324796ABM2601_01

Management, I., \& Education, H. (2007). Higher Education Management and Policy. Journal Oj the Programme on Institutional Management Wm Higher Education. https://doi.org/10.1787/hemp-v17-3-en

Masditou. (2017). Manajemen Pembiayaan Pendidikan Menuju Pendidikan Yang Bermutu. Jurnal ANSIRU PAI. 
Nugroho, H. (2002). Mcdonalisasi Pendidikan Tinggi. Yogyakarta: Kanisius.

Nurdin. (2009). Pro Kontra Undang-Undang BHP dalam Konteks Mutu Pendidikan. Jurnal Administrasi Pendidikan, 9(1).

PH, S. (2014). Politik Pendidikan Indonesia Dalam Abad Ke-21. Jurnal Cakrawala Pendidikan, 3(3), 324-337. https://doi.org/10.21831/cp.v3i3.2377

Pratomo, H. (2002). TANTANGAN PENDIDIKAN DALAM RANGKA PELAKSANAAN OTONOMI DAERAH. Cakrawala Pendidikan, 1(1). https://doi.org/10.21831/cp.v1i1.7472

Putra, G. R. . (2012). Politik Pendidikan: Liberalisasi Pendidikan Tinggi Periode 2000-2012 (Studi Komparasi: Indonesia dan India). Depok: Universitas Indonesia.

Rahardjo, M. (2010). Pemikiran Kebijakan Pendidikan Kontemporer. Malang: UIN Maulana Malik Ibrahim Press.

Raychaudhuri, A., \& De, P. (2007). Barriers on Trade in Higher Education Services: Empirical Evidence from Asia Pacific Countries. Asia Pacific Trade and Investment Review, 3(2).

Rizvi, F., \& Lingard, B. (2010). Globalizing Education Policy. New York: Routledge.

Sandhu, R. (2015). Autonomy And Accountability In Higher Education. International Journal of Research in IT, Management and Engineering, 5(1).

Sangaji, A. (2013). neoliberalisme. Jurnal Pergerakan Progresif, III.

Simangunsong, B. (2018). Korupsi sebagai Musuh Bersama: Merekonstruksi Spiritualitas Anti Korupsi dalam Konteks Indonesia. BIA': Jurnal Teologi Dan Pendidikan Kristen Kontekstual. https://doi.org/10.34307/b.v1i2.52

Soeharto, K. (2010). Perdebatan Ideologi Pendidikan. Jurnal Cakrawala Pendidikan, 2(2), 134-146. https://doi.org/10.21831/cp.v2i2.334

Solihin, M. (2015). Kapitalisme Pendidikan (Analisis Dampaknya Terhadap Upaya Mencerdaskan Kehidupan Bangsa). Nur El -Islam.

Sonhadji, A. (2014). Manusia, Teknologi, dan Pendidikan Menuju Peradaban Baru. Malang: Universitas Negeri Malang Press.

Suharsaputra, U. (2015). Manajemen Pendidikan Perguruan Tinggi: Strategi Menghadapi Perubahan. Bandung: PT Refika Aditama.

Susanti, D. (2012). Privatisation and Marketisation of Higher Education in Indonesia: The Challenge for Equal Access and Academic Values. Higher Education, 61(2), 209-218. https://doi.org/10.1007/s10734-010-9333-7

Swasono, E. (2015). Ekonomi Cukup: Kritik Budaya pada Kapitalisme. Jakarta: PT Kompas Media Nusantara.

Tilaar. (2012). Kaleidoskop Pendidikan Nasional. Jakarta: Kompas Media Nusantara.

Triharso, A. (2015). Pendidikan Tinggi Dan Intelektualisme: Revitalisasi Ideologi Dan Menumbuhkan Modal Sosial Bangsa Menghadapi Persaingan Internasional Dan Global. Malang: Madani.

Van Der Wende, M. C. (2003). Globalisation and Access to Higher Education. Journal of Studies in International Education, 7(2), 193-206. https://doi.org/10.1177/1028315303007002006

Wilson, M. A. F. (2017). Neoliberal ideology in a private Sudbury school. Policy 
Futures in Education, 15(2), 170-184. https://doi.org/10.1177/1478210315610256

Zainuddin. (2008). Reformasi Pendidikan: Kritik Kurikulum dan Manajemen Berbasis Sekolah. Yogyakarta: Pustaka Belajar. 